\title{
Protective and Catching Safety Systems In Construction
}

\author{
Marat Kuzhin ${ }^{1 *}$ \\ ${ }^{1}$ Moscow State University of Civil Engineering, 129337 Moscow, Russia
}

\begin{abstract}
In the article is described application of protective and catching systems in construction. Classification of similar systems, their types and purpose are listed. Dangerous zones on construction site and events to for limiting their influence or protection from the factors. Protective and catching systems is one of the most effective technical equipment, applied in recent time. Protective fences and catching systems are important part in the problem solution. Protective fences protect workers from falling from height. Protective and catching systems allows avoid injuries by workers, also catch debris, fallen from constructing buildings. In regard with continuing development in technical and technological solutions, protective and catching systems require adaptation to a new requirements of construction industry and requirements of normative documents. Technical regulations in the appliance sphere of protective and catching systems requires actualization and aligning with modern normatives. Important role should be given to developing organizational and technological documentation for application of the systems. Scientific studying of technical parameters of fences and protective catching nets also has great interest.
\end{abstract}

\section{Introduction}

Ensuring the required level of safety in construction industry is one of the major condition of project functioning and realization. Construction work have a lot of dangerous production factors, among which the most common are production work near an edge of buildings and work production in dangerous zones, appeared from objects falling from a building [14-17]. Modern conditions of construction assumes work production in tight urban conditions, what causes limits in construction production, which need to be considered in organizational and technological construction projecting $[7,10,11,13]$. In construction applied two kind of systems, protecting from falling objects: passive and active systems. Passive systems, while installed, protect workers without necessity of their participation in system activity. Active systems require each worker himself take action, from falling protection, such as wearing safety belt. In the article will be discussed only passive systems like safety nets and protective fences (fig.1).

\footnotetext{
Corresponding author: kuzhinmf@mail.ru
} 


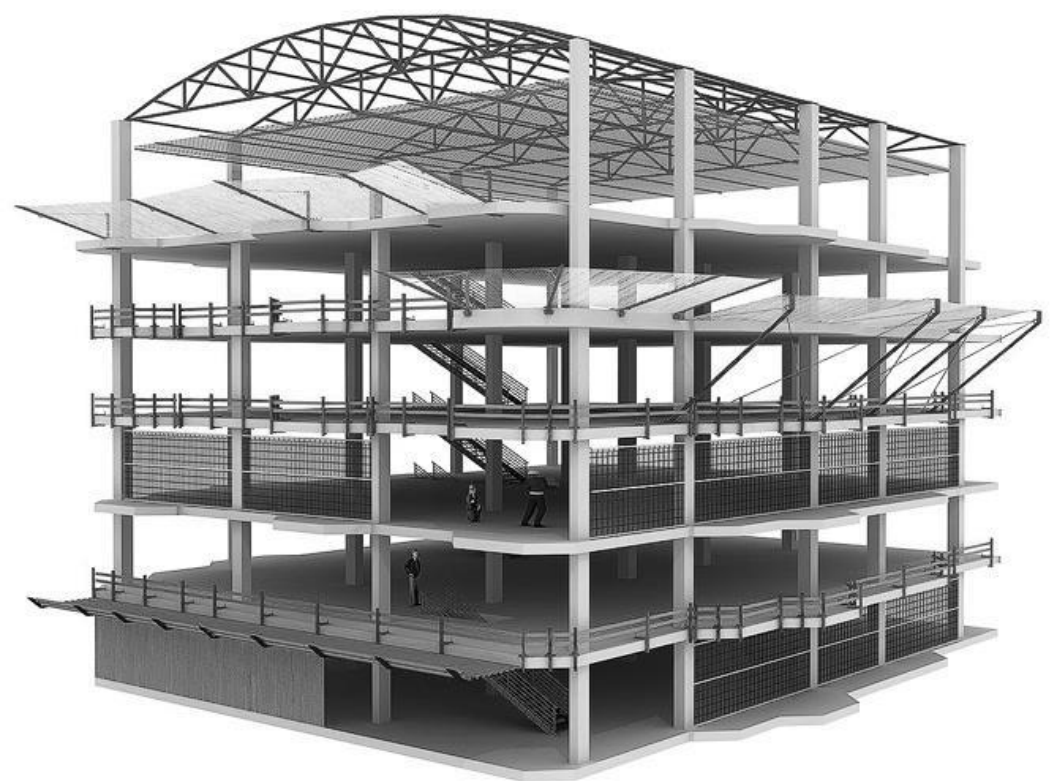

Fig. 1. Protective and catching systems, installed on object.

Nowadays in sphere of application protective and catching systems exists following documents, regulating appliance of such systems:

1)GOST 12.4.059-89 Stroitelstvo. Ograzhdenia predohranitelnie inventarnie;

2)DIN EN 13374 Temporary edge protection systems. Product specification -Test methods;

3)DIN EN 1263-1 Part 1: Safety requirements, test methods.

4)DIN EN 1263-1 Part 2: DIN EN 1263-1 Part 2: Safety requirements for the positioning limits.

Review of the given documents shows that existing normative and technical documents regulates methods of testing and requirements for geometrical characteristics. And there is not enough information about technological and organizational issues [1-5].

\section{Results and Discussion}

Construction presents difficult system, which consists of working contract organizations, constantly moving materials and technical resources, machines and mechanisms, also temporary infrastructure, necessary for providing relevant conditions. Construction object is motionless element of such system, on which construction works are underway. Construction always causes appearance on territory dangerous production factors, related with work of installing machines and lifting mechanisms, with .works near border of high difference. Listed above factors can be divided into two groups: constantly-acting and temporary-acting (table 1).

Table 1. Dangerous areas on construction site and ways for their limitation

\begin{tabular}{|c|c|c|c|c|}
\hline № & Kind of factor & Work type & Relative dimensions & way for limitation \\
\hline
\end{tabular}




\begin{tabular}{|c|c|c|c|c|}
\hline 1 & $\begin{array}{c}\text { Dangerous area } \\
\text { from crane }\end{array}$ & $\begin{array}{c}\text { Works, made with } \\
\text { crane }\end{array}$ & $\begin{array}{c}\text { Under crane boom } \\
\text { with weight }\end{array}$ & $\begin{array}{c}\text { Overhang limitation } \\
\text { and rotation angle } \\
\text { limitation }\end{array}$ \\
\hline 2 & $\begin{array}{c}\text { Dangerous area } \\
\text { around building }\end{array}$ & Construction work & $\begin{array}{c}\text { Repeats building's } \\
\text { border } \\
\text { catching nets, } \\
\text { protective screens, } \\
\text { canopy above } \\
\text { passes }\end{array}$ \\
\hline 3 & $\begin{array}{c}\text { Dangerous area } \\
\text { from remote deck }\end{array}$ & $\begin{array}{c}\text { At lifting and material } \\
\text { unloading }\end{array}$ & $\begin{array}{c}\text { On a contour of } \\
\text { remote deck }\end{array}$ & $\begin{array}{c}\text { Passive protection } \\
\text { as a marking on the } \\
\text { deck }\end{array}$ \\
\hline 4 & $\begin{array}{c}\text { Dangerous area of } \\
\text { lifting } \\
\text { mechanisms }\end{array}$ & $\begin{array}{c}\text { Lifting construction } \\
\text { materials on a floor }\end{array}$ & $\begin{array}{c}\text { On a contour of } \\
\text { lifting mechanism }\end{array}$ & $\begin{array}{c}\text { Passive protection } \\
\text { as a marking on the } \\
\text { deck }\end{array}$ \\
\hline 5 & Height difference & Work near an edge & $\begin{array}{c}\text { Border of dangerous } \\
\text { area }\end{array}$ & Protective fences \\
\hline
\end{tabular}

Protective and catching system is one of the most effective technical equipment applied in recent years. Such systems according to type of work can have different purpose (table 2). Protecting fences and protective and catching systems are important part in the problem solution. Protecting fences prevent workers from falling from the height. Protectivecatching nets allows avoid injuries, and also catch objects, fallen from constructing buildings [18-21,24].

Table 2. Comparison of fences according to existing norms

\begin{tabular}{|c|c|c|c|}
\hline № & Name & Purpose & Withstand loads \\
\hline \multicolumn{4}{|c|}{ GOST 12.4.059-89 Stroitelstvo. Ograzhdenia predohranitelnie inventarnie } \\
\hline 1 & Preventing fences & $\begin{array}{l}\text { Fencing working places on the } \\
\text { height and passes to them, } \\
\text { construction of which placed } \\
\text { in vertical position, used for } \\
\text { preventing from falling }\end{array}$ & - \\
\hline 1.1 & Protective fences & $\begin{array}{l}\text { Protective fence, used for } \\
\text { preventing unintentional } \\
\text { accessto border of height } \\
\text { difference }\end{array}$ & $\begin{array}{c}\text { Protective fences } \\
\text { calculated on strength } \\
\text { and stability to } \\
\text { alternately acting } \\
\text { horizontal and vertical } \\
\text { evenly spread loads } 400 \\
\text { H/M. } \\
\end{array}$ \\
\hline 1.2 & Insurance fences & $\begin{array}{l}\text { Protecting fence providing } \\
\text { retention when people loose } \\
\text { stability near border of height } \\
\text { difference }\end{array}$ & $\begin{array}{c}\text { Calculated on strength } \\
\text { and stability of acting } \\
\text { horizontal fixed force, } \\
\text { not lower than } 700 \mathrm{H}, \\
\text { and insurance exterior } \\
\text { calculated on strength for } \\
100 \mathrm{~kg} \text {, falling from } 1 \mathrm{~m} \\
\text { height. }\end{array}$ \\
\hline 1.3 & Signal fences & $\begin{array}{l}\text { Preventing fences, used for } \\
\text { marking dangerous zones }\end{array}$ & 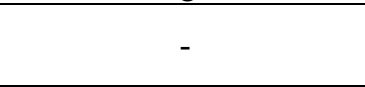 \\
\hline \multicolumn{4}{|c|}{ According to DIN EN 13374 Temp. edge protection systems. } \\
\hline 2.1 & Fences class $\langle A »$ & Class A protection provides & For posts and guardrails, \\
\hline
\end{tabular}




\begin{tabular}{|c|c|c|c|}
\hline & & $\begin{array}{l}\text { resistance to static loads only, } \\
\text { based on the requirements to: } \\
\text { support a person leaning on } \\
\text { the protection or provide a } \\
\text { handhold when walking } \\
\text { beside it; and collectively stop } \\
\text { a person who is walking or } \\
\text { falling towards the protection. }\end{array}$ & $\begin{array}{c}F \mathrm{~T} 1=300 \mathrm{~N} . \\
\text { For toeboards, } F \mathrm{~T} 2= \\
200 \mathrm{~N} .\end{array}$ \\
\hline 2.2 & Fences class $\langle\mathrm{B} »$ & $\begin{array}{l}\text { Class B protection provides } \\
\text { resistance to static loads and } \\
\text { low dynamic actions only, } \\
\text { based on the } \\
\text { requirements to: support a } \\
\text { person leaning on the } \\
\text { protection or provide a } \\
\text { handhold when walking } \\
\text { beside it; and collectively stop } \\
\text { a person who is walking or } \\
\text { falling towards the protection; } \\
\text { collectively stop a person } \\
\text { sliding/falling down a sloping } \\
\text { surface. }\end{array}$ & $\begin{array}{l}\text { Class B edge protection } \\
\text { system shall fulfil the } \\
\text { design requirements } \\
\text { given in clause to class A } \\
\text { Class B edge protection } \\
\text { system shall be capable } \\
\text { of absorbing a kinetic } \\
\text { energy of } 1100 \mathrm{~J} \\
\text { anywhere along the } \\
\text { protection up to a height } \\
\text { of } 200 \text { mm above the } \\
\text { working surface and } 500 \\
\mathrm{~J} \text { at all higher parts. }\end{array}$ \\
\hline 2.3 & Fences class $« \mathrm{C} »$ & $\begin{array}{l}\text { Class C protection provides } \\
\text { resistance to high dynamic } \\
\text { forces based on the safety } \\
\text { requirements to prevent } \\
\text { the fall of a person sliding } \\
\text { down a steep sloping surface. } \\
\text { Collectively stop a person } \\
\text { sliding/falling down a steep } \\
\text { sloping surface. }\end{array}$ & $\begin{array}{l}\text { Class } \mathrm{C} \text { has no static load } \\
\text { requirement. } \\
\text { Class } \mathrm{C} \text { edge protection } \\
\text { system shall be capable } \\
\text { of absorbing } 2200 \mathrm{~J} \text { of } \\
\text { kinetic energy anywhere } \\
\text { along the } \\
\text { protection up to a height } \\
\text { of } 200 \mathrm{~mm} \text { above the } \\
\text { working surface and } 500 \\
\mathrm{~J} \text { at all higher parts. }\end{array}$ \\
\hline
\end{tabular}

Catching systems also well known as safety nets appeared several years ago. Nowadays, there 4 main types of it. Each type is designed for a specific situation and construction phase (table 3).

Table 3. Comparison of fences according to existing norms

\begin{tabular}{|c|c|c|c|}
\hline № & Name & Purpose & Withstand loads \\
\hline \multicolumn{3}{|c|}{ According to DIN EN 1263-1 Safety nets } \\
\hline 1.1 & System type «T» & $\begin{array}{c}\text { Holding construction garbage } \\
\text { and workers, fell from the } \\
\text { working horizon }\end{array}$ & $\begin{array}{c}\text { Static tests for finding } \\
\text { loads of tear. Dynamic } \\
\text { tests with load 100 kg. }\end{array}$ \\
\hline 1.2 & System type «S» & $\begin{array}{c}\text { Holding construction garbage } \\
\text { and workers, fell from the } \\
\text { working horizon }\end{array}$ & $\begin{array}{c}\text { Static tests for finding } \\
\text { loads of tear. Dynamic } \\
\text { tests with load 100 kg. }\end{array}$ \\
\hline 1.3 & System type «V» & Holding construction garbage & $\begin{array}{c}\text { Static tests for finding } \\
\text { loads of tear. Dynamic } \\
\text { tests with load 100 kg. }\end{array}$ \\
\hline
\end{tabular}




\begin{tabular}{|c|c|c|c|}
\hline 1.4 & System type «U» & $\begin{array}{c}\text { Static tests for finding } \\
\text { loads of tear. Dynamic } \\
\text { tests with load } 75 \mathrm{~kg} \\
\text { rolling on inclined } \\
\text { surface }\end{array}$ \\
\hline
\end{tabular}

Classification of protective fences according to [1] and [5] have common requirements, differences only in character of applied loads and their type.

\section{Conclusions}

Accounting of all above listed dangerous production factors is necessary condition for providing safety in construction $[6,8,9,12]$. In recent years technical solutions and equipment, needed for decision the problems, got a significant development. In accordance with their application causes additional expenses of time and work, which influences on construction period, technical decisions of such systems need constantly improvement. However, existing solutions allows provide minimal required level of protection from most of the factors $[22,23]$.

According to constantly improving technical and technological solutions, protectivecatching systems also need constant adaptation for modern requirements of construction production and requirements of normative documents. Technical regulations in applying protective-catching system sphere requires modernization and alignment with modern norms. Important role should be given to projecting organizational and technological documentation for using the systems. Scientific studying of technical parameters of fences and protective-catching nets also has great interest.

\section{References}

1. GOST 12.4.059-89 Stroitelstvo. Ograzhdenia predohranitelnie inventarnie

2. SNiP 12-03-2001 Bezopasnost truda v stroitelstve

3. Prikaz Ministerstva truda i socialnoi zashiti RF ot 1 iuna № 336n "Ob utverzhdenii Pravil po ohrane truda v stroitelstve" (2015)

4. DIN EN 1263-1 Safety nets, English version (2002)

5. DIN EN 13374 Temporary edge protection systems. English version (2013)

6. Lyapin, A., Korolchenko, A., Meshalkin, E. Analysis of causes of combustible mixture explosions inside production floor areas. (2016) MATEC Web of Conferences, 86, art. no. 04030 . DOI: $10.1051 /$ matecconf $/ 20168604030$

7. B.V. Zhadanovskiy, M.F. Kuzhin Organizacionno-technologicheskie reshenia ustroistva navesnih fasadnih sistem pri reconstrukcii zhilih i obshestvennih zdaniy //Promishlennoe i grazhdanskoe stroitelstvo. № 1. P. 62-64 (2012)

8. Korolchenko A.Ya., Petrova E.A. Modern means for protection of wood against flame. (2003) Rossijskij Khimicheskij Zhurnal (Zhurnal Rossijskogo Khimicheskogo Obshchestva Im. D.I. Mendeleeva), 47 (4), pp. 49-55

9. Shebeko Yu.N., Tsarichenko S.G., Trunev A.V., Korolchenko A.Ya., Kaplin A.Yu. The influence of inert retardants on the combustion of hydrogen-oxygen mixtures under elevated temperatures and pressures. (1994) Combustion, Explosion, and Shock Waves, 30 (2), pp. 183-188. DOI: 10.1007.

10. B.V. Zhadanovskiy, S.A. Sinenko Pressure Method of Monolithic Concrete Structures of Buildings and Structures // International Journal of Applied Engineering, Research 11, Number 3, pp.1724-1727 (2012) 
11. A.A. Lapidus, N.D. Cherednichenko The Impact of Technology Installation of Injection Mortar Systems for a Long Term Behavior of Anchor Connections // Procedia Engineering, 153, pp.371-377 (2014)

12. D.A. Korolchenko, A.F. Sharovarnikov Universalnost mechanizmov tusheniya plameni razlichnimi ognetushshimi veshestvami //Pozharovzrivobezopasnost. -T. 23, № 11. -P. 84-88 (2014)

13. A.A. Lapidus, A.A. Makarov Model for the Potential Manufacture of Roof Structures for Residential Multi-storey Buildings // Procedia Engineering, 153, pp.378-383 (2013)

14. P.P. Oleynik, V.I. Brodskiy Tehnicheskoe regulirovanie organizacii bezopasnosti truda v stroitelstve. Zhurnal TOSP, №1, p.27-32 (2014)

15. B.F. Shirshikov, S.A. Sinenko, A.M. Slavin, B.V. Zhadanovskiy, M.F. Kuzhin, V.I. Brodskiy Organizacionno-tehnologicheskie resheniya po bezopasnosti truda $\mathrm{v}$ proectah proizvodstva rabot. Moscow (2015)

16. S.A. Bocheev, M.F. Kuzhin Organizacionno-tehnologicheskie osobennosti proizvodstva fasadnih rabot. Sbornik: Integracii, partnerstvo i innovacii $\mathrm{v}$ stroitelnoy nauke $\mathrm{i}$ obrazovanii, p.229-234 (2017)

17. U.A. Vilman, M.F Kuzhin. Meropriyatiya po ogranicheniu opasnih zon na stroitelnoy ploshadke. Nauchnoye obozrenie, №17, p.341-344 (2015)

18. McCabe, B.Y., Alderman, E., Chen, Y., Hyatt, D.E., Shahi, A. Safety Performance in the Construction Industry: Quasi-Longitudinal Study Journal of Construction Engineering and Management Volume 143, Issue 4, 1 April 2017, Article number 04016113 .

19. Fang, Y. ,Cho, Y.K. Effectiveness Analysis from a Cognitive Perspective for a RealTime Safety Assistance System for Mobile Crane Lifting Operations Journal of Construction Engineering and Management Volume 143, Issue 4, 1 April 2017, Article number 05016025.

20. Kim, H. , Ahn, C.R. , Yang, K. Identifying Safety Hazards Using Collective Bodily Responses of Workers Journal of Construction Engineering and Management Volume 143, Issue 2, 1 February 2017, Article number 04016090.

21. Park, J., Marks, E. , Cho, Y.K.,Suryanto, W Performance test of wireless technologies for personnel and equipment proximity sensing in work zones Journal of Construction Engineering and Management Volume 142, Issue 1, 1 January 2016, Article number 04015049.

22. Korolchenko D. A.; Degaev E. N.; Sharovarnikov A. F. Dependence of Fire Extinguishing Efficacy of Low Expansion Foams Solutions Homology Sodium Sulfate on the Molecular Weight of the Surface-active Substances 2015 2nd International conference on material engineering and application (ICMEA 2015)

23. Korolchenko D., Tusnin A., Trushin S., Korolchenko A. Physical parameters of high expansion foam used for fire suppression in high-rise buildings, International Journal of Applied Engineering Research, Volume 10, Issue 21, 2015, Pages 42541-42548.

24. Pomares, J.C., Irles, R., Segovia, E. , Ferrer, B. Acceleration and deflection analysis for class $\mathrm{C}$ edge protection systems in construction work Journal of Construction Engineering and Management Volume 140, Issue 8, 1 August 2014, Article number 04014031. 